\title{
DỰ BÁO BIẾN ĐộNG CHÂT LƯợNG NƯỚC SÔNG HẬU DO QUÁ TRİNH NÂNG CÔNG SUẤT NHÀ MÁY GIẤY LEE AND MAN VIẸTT NAM
}

\author{
Ngô Trà Mai ${ }^{1}$, Phan Thị Thanh Hằng ${ }^{2}$
}

Tóm tắt: Việc nâng công suất Nhà máy giấy Lee \& Man Việt Nam tù 420.000 tấn/năm lên

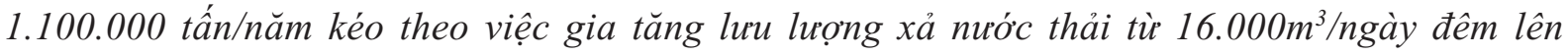
$33.400 m^{3} / n g a ̀ y$ đêm, đồng nghĩa với việc tăng hàm lương các chất thải đổ vào sông Hậu. Nghiên cưu này trình bày kết quả áp dụng bộ mô hình MIKE mô phỏng 04 kịch bản lan truyền $B_{0} D_{5}, C O D$ và TSS là các thành phần đặc trung trong nước thải của ngành tái chế giấy làm co sở để dụ báo biến động chất lượng nuớc sông Hậu.

Từ khóa: Nhà máy giấy, nước thải và mô hình MIKE.

Ban Biên tập nhận bài: 11/12/2019 Ngày phản biện xong: 12/12/2019 Ngày đăng bài: 20/12/2019

\section{Mở đầu}

Tháng 11/2017, Nhà máy giấy Lee \& Man Việt Nam chính thức vận hành tại ấp Phú Thạnh, thị trấn Mái Dầm, huyện Châu Thành, tỉnh Hậu Giang gồm 1 xưởng sản xuất 420.000 tấn/năm. Sản phẩm đầu ra là giấy Krafliner và Whitetop, nguyên liệu đầu vào là giấy phế liệu nhập khẩu 504.000 tấn/năm. Tháng 9/2019 Nhà máy quyết định tăng công suất lên 1.100 .000 tấn/năm bằng cách nâng cấp xưởng sản xuất hiện hữu lên 500.000 tấn/năm và đầu tư bổ sung thêm 1 xưởng sản xuất 600.000 tấn/năm công nghệ tương tự.

Quá trình nâng công suất làm tăng lượng nước thải từ $16.000 \mathrm{~m}^{3}$ lên $33.400 \mathrm{~m}^{3} /$ ngày đêm [1]. Nước thải từ công đoạn: nghiền thủy lực, lọc nồng độ cao, sàng thô, lọc đĩa, ép và sấy sơ bộ, thành phần ô nhiễm chủ yếu là chất rắn lơ lửng (SS), chất hữu cơ $\left(\mathrm{BOD}_{5} / \mathrm{COD}\right)$, chất dinh dưỡng $(\mathrm{N} / \mathrm{P})$ sẽ được xử lý và đổ thải vào sông Hậu.

Tại sông Hậu, quá trình thuỷ động lực (dòng chảy, gió, quá trình xáo trộn,...) làm khuếch tán các chất đồng thời mang khối nước thải này lên phía bắc hoặc xuống phía nam theo hướng dòng chảy. Nghiên cứu ảnh hưởng của khối nước thải từ Nhà máy Giấy thông qua các mô hình toán để mô phỏng quá trình vật lý, sinh hóa diễn ra trong lưu vực. Kết quả tính toán mô phỏng liên tục quá trình động lực và truyền tải vật chất trong trường hợp trường hợp Nhà máy trước và sau khi nâng công suất, cũng như mô phỏng các kịch bản khác nhau trong những điều kiện xả thải khác nhau. Việc mô phỏng theo các kịch bản khác nhau hỗ trợ các nhà ra quyết định xem xét có hay không chấp thuận nâng công suất cho Nhà máy; giúp các nhà quản lý đưa ra được những kế hoạch, chiến lược để kiểm soát và điều tiết nguồn thải; đồng thời khuyến cáo Nhà máy xây dựng các biện pháp sản xuất sạch hơn, tuần hoàn nước thải, giảm thiểu các tác động bất lợi đến nguồn tiếp nhận.

\section{Phương pháp nghiên cứu và tài liệu thu} thập

\subsection{Tiếp cận vấn đề}

Có nhiều cách tiếp cận trong nghiên cứu thủy văn và môi trường. Tuy nhiên quan điểm tiếp cận tổng thể được sử dụng chính trong nghiên cứu: các biến động ô nhiễm được xem xét trong các mối quan hệ giữa tự nhiên và kinh tế xã hội trên lưu vực sông Hậu và lân cận.

\subsection{Lưa chọn mô hình}

Để tính toán mức độ lan truyền ô nhiễm do nước thải trên sông Hậu, sử dụng các mô hình Nam, Mike 11 và Mike 21. 
Sử dụng NAM như một biểu thức toán học để kết nối mô tả theo dạng định lượng đơn giản các thành phần khác nhau của quá trình mưa - dòng chảy.

Sử dụng MIKE 11, 21 là phần mềm kỹ thuật chuyên dụng của DHI (Viện Thuỷ lực Đan
Mạch) để mô phỏng thuỷ động lực của các dòng chảy. Hệ thống mô hình có khả năng sử dụng cả lưới tính toán đường thẳng cũng như đường cong để tính toán chất lượng nước trong sông, biển và hồ chứa. Quá trình tính toán được thực hiện trong hình 1.

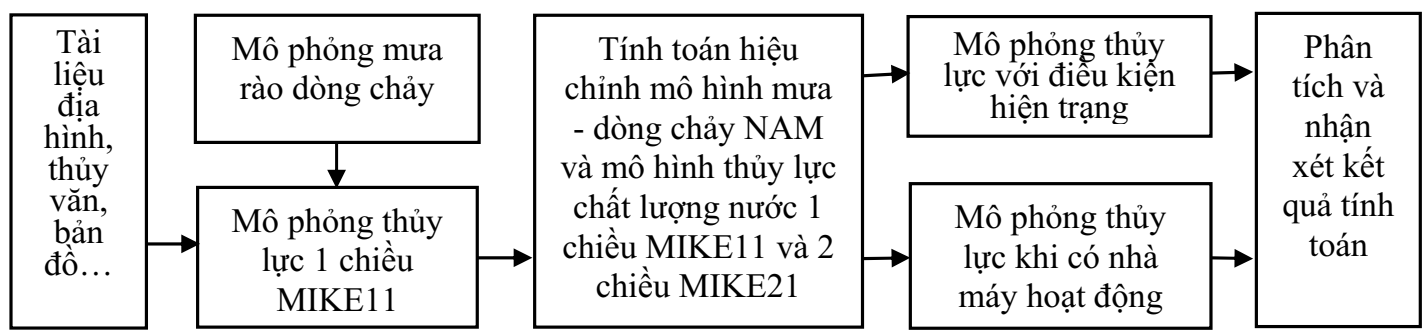

Hình 1. Qui trình tính toán

\subsection{Thiết lập điều kiện biên}

Để làm biên cho mô hình 2 chiều, mô hình 1 chiều kết hợp với mưa dòng chảy (NAM) được xây dựng và mô phỏng. Do khối lượng mô hình lớn nên trong Dự án này sử dụng kết quả mô phỏng của Viện Khoa học Khí tượng Thủy văn và Môi trường [2]. Sơ đồ thủy lực được đưa ra tại hình 2.

Do đặc điểm tự nhiên của khu vực Nhà máy nằm giáp ranh giữa ĐBSCL và hạ lưu sông Sài Gòn - Đồng Nai nên để mô hình hoá được chế độ thuỷ lực mùa kiệt/mùa lũ của toàn vùng, sơ đồ tính toán thuỷ lực phải thiết lập cho toàn vùng ĐBSCL từ Karatie tới biển Đông và toàn bộ khu vực hạ lưu sông Đồng Nai từ Phước Hòa, Dầu Tiếng và Trị $A n$ đến biển. Sơ đồ này được kết nối từ 2 sơ đồ tính là thủy lực cho hạ lưu sông Sài Gòn - Đồng Nai và toàn ĐBSCL [2-3].

Biên lưu lượng gồm 03 biên: tại Karatie, Biển hồ và Vàm Cỏ Đông. Biên mực nước gồm 65 biên, kéo dài từ cửa Thị Vải đến cửa ra kênh Vĩnh Tế. Do mô hình thủy lực 2 chiều không áp dụng được cho vùng lớn vì tốc độ máy tính không cho phép, nên phạm vi của mô hình này từ Cần Thơ đến Đại Ngải với chiều dài khoảng 40 $\mathrm{km}$ bao phủ toàn bộ vùng có hoạt động xả thải của Nhà máy (Hình 3). Các biên của mô hình MIKE 21 được lấy từ mô hình 1 chiều MIKE 11 . Sơ đồ thủy lực cho vùng Dự án được chia thành 1.000.000 ô lưới tính toán (2000x500) (Hình 4).

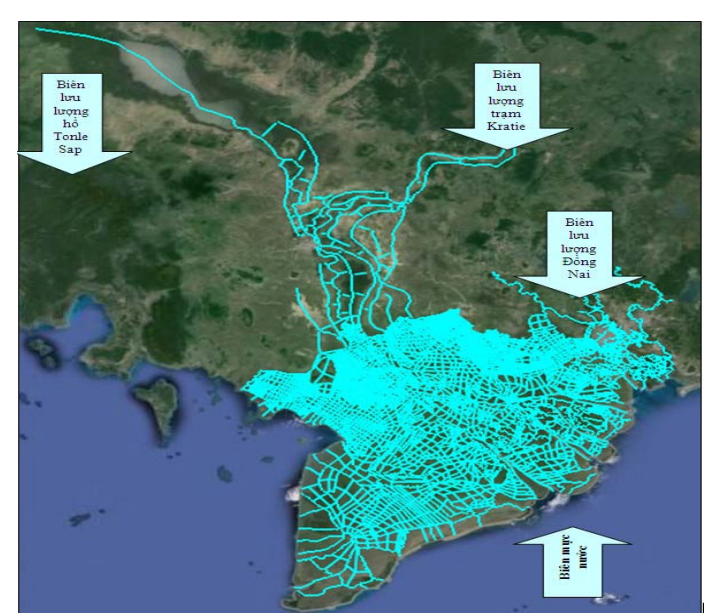

Hình 2. So đồ thủy lực vùng có hoạt động xả thải của Nhà máy giấy

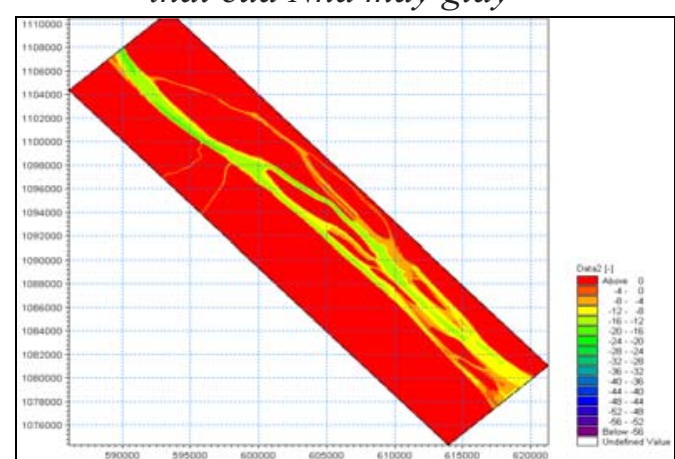

Hình 3. Sơ đồ thủy lự 2 chiều toàn khu vực

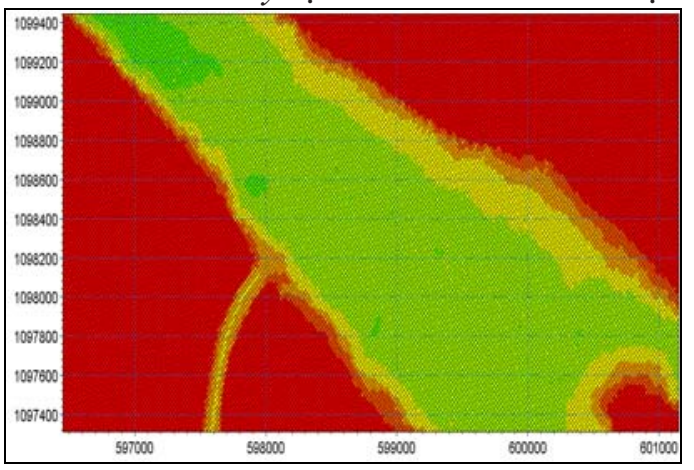

Hình 4. Ô lưới tính toán trong so đồ thủy lực TẠP CHÍ KHÍ TƯợNG THỦY VĂN Số phục vụ Hội thảo chuyên đề 


\section{BÀI BÁO KHOA HỌC}

\subsection{Xây dụng kịch bản mô phỏng}

Cù lao Mây nằm giữa sông Hậu, thuộc địa phận xã Lục Sĩ Thành (phía Nam) và xã Phú Thành (phía Bắc), huyện Trà Ôn, tỉnh Vĩnh Long, cách điểm xả nước thải của Nhà máy khoảng $900 \mathrm{~m}$ về phía Đông Bắc; Cù lao Phong Nẫm, là một xã cù lao thuộc huyện Kế Sách, tỉnh Sóc Trăng, cách vị trí điểm xả nước thải của Nhà máy Giấy khoảng 4,9km về phía Đông Nam.

Xây dựng các trường hợp mô phỏng để so sánh đối chứng khi Nhà máy nâng công suất.

- Kịch bản 1, 3: Nước thải sản xuất của Nhà máy Giấy công suất 420.000 và 1.100 .000 tấn/năm chưa được xử lý (rủi ro/sự cố), xả trực tiếp ra môi trường. Nồng độ $\mathrm{COD}, \mathrm{BOD}_{5}$, TSS trong kịch bản 1 được lấy theo thực tế tại kết quả đo đạc chất lượng nước thải trước xử lý của Nhà máy công suất 420.000 tấn/năm trong 6 tháng, bảng 1 .
- Kịch bản 2, 4: Nước thải sản xuất của Nhà máy Giấy công suất 420.000 và 1.100 .000 tấn/năm xử lý đạt QCVN 12-MT:2015/BTNMT, QCVN 40:2011/BTNMT, cột $A, K_{q}=1,2 ; K_{f}=0,9$. Nồng độ $\mathrm{COD}, \mathrm{BOD}_{5}$, TSS lấy bằng giới hạn cho phép của 2 quy chuẩn (Bảng 1).

Kết quả sẽ được so sánh giữa kịch bản 1 và 3,2 và 4 để xem xét biến động về lưu lượng, nồng độ, khoảng cách lan truyền chất thải khi nâng công suất Nhà máy.

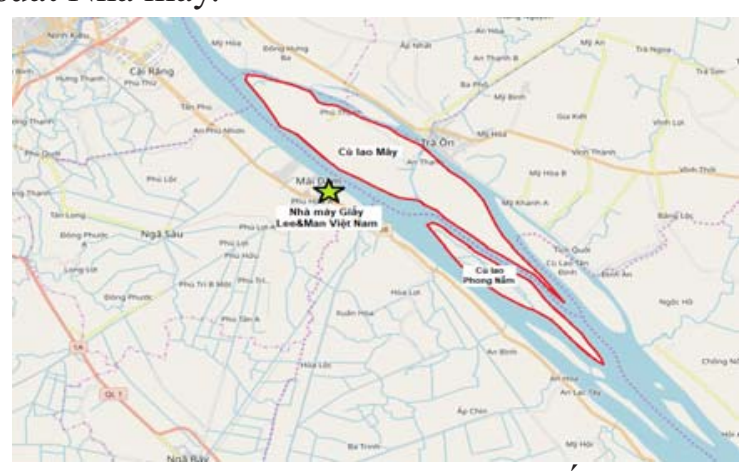

Hình 5. Vị trí nhà máy giấy

Bảng 1. Tính chất nước thải sản xuất (trước xủ̉ lý) theo kết quả quan trắc định kỳ 6 tháng đầu năm 2019 của Nhà máy Giấy đang hoạt động với công suất 420.000 tấn/năm

\begin{tabular}{cccccccccc}
\hline \multirow{2}{*}{ Thông số } & Đv & \multicolumn{9}{c}{ Nồng độ (tháng) } & & QCVN 12- & QCVN \\
\cline { 3 - 10 } & & $1 / 2019$ & $2 / 2019$ & $3 / 2019$ & $4 / 2019$ & $5 / 2019$ & $6 / 2019$ & $\begin{array}{c}\text { MT:2015/B } \\
\text { TNMT }\end{array}$ & $\begin{array}{c}\text { 40:2011/ } \\
\text { BTNMT }\end{array}$ \\
\hline COD & $\mathrm{mg} / 1$ & 2.625 & 2.888 & 3.676 & 2.871 & 3.303 & 2.867 & 81 & 81 \\
\hline BOD $_{5}$ & $\mathrm{mg} / 1$ & 1.333 & 1.277 & 1.804 & 1.456 & 1.561 & 1.398 & 32,4 & 32,4 \\
\hline TSS & $\mathrm{mg} / 1$ & 17.673 & 15.760 & 1.427 & 3.688 & 1.936 & 708 & 54 & 54 \\
\hline
\end{tabular}

Ghi chú: QCVN 12-MT:2015/BTNMT, quy chuẩn về nuớc thải công nghiệp giấy và bột giấy; QCVN 40:2011/BTNMT, quy chuẩn về nước thải công nghiệp

\section{Kết quả và thảo luận}

Hiệu chỉnh và kiểm định mô hình: Đối với trường hợp của Nhà máy giấy Lee and Man Việt Nam đã có hoạt động với công suất 420.000 tấn/năm từ tháng 11/2017. Sử dụng số liệu đo thực tế để làm cơ sở kiểm định mô hình. Hiện nay, Trạm XLNTTT của Nhà máy hoạt động hiệu quả, nồng độ các chất ô nhiễm trong nước thải sau xử lý đều nằm trong giới hạn của $\mathrm{QCVN}$ 12-MT:2015/BTNMT và QCVN 40:2011/BTNMT, cột A, $K_{q}=1,2 ; K_{f}=0,9$. So sánh kết quả chạy mô hình với báo cáo giám sát môi trường định kỳ của Nhà máy Giấy hiện hữu cho thấy:

- Tại vị trí cách cửa xả thải $100 \mathrm{~m}$ về phía thượng lưu (trên sông Hậu): nồng độ $\mathrm{BOD}_{5}$,
COD và TSS tính toán tuy không trùng khớp hoàn toàn với kết quả đo đạc giám sát môi trường định kỳ nhưng cũng nằm trong khoảng dao động của số liệu giám sát (BOD 5 : 4-4,8 mg/l; COD: 5,2-6,4 mg/l; TSS: 12,74-12,78mg/l).

- Tương tự, tại vị trí cách cửa xả thải $100 \mathrm{~m}$ về phía hạ lưu (trên sông Hậu): nồng độ BOD5, $\mathrm{COD}$ và $\mathrm{TSS}$ cũng nằm trong khoảng dao động của số liệu giám sát (BOD 5 : 3,8-4,9 mg/1; COD: 5-6,5 mg/1; TSS: 12,74-12,8 mg/1).

Qua kết quả hiệu chỉnh và kiểm định xác định được chỉ số Nash dao động từ 0,77 đến 0,99 . Như vậy, việc áp dụng kết hợp hai modun MIKE 11 và MIKE 21 để mô phỏng diễn biến của hàm lượng các yếu tố $\mathrm{BOD}_{5}, \mathrm{COD}$ và TSS trong nước sông Hậu. Như vậy, kết quả sử dụng mô hình 
MIKE 21 để dự báo phạm vi lan truyền và nồng độ các chất ô nhiễm trong nước thải tại các khoảng cách cho kết quả tin cậy, có thể tiếp tục áp dụng để dự báo cho giai đoạn nâng công suất của Nhà máy lên 1.100 .000 tấn/năm

\subsection{Kịch bản 1, 3 nước thải sản xuất trước} và sau khi nâng công suất chưa được xử lý

- Hàm lượng $\mathrm{BOD}_{5}$ trên sông Hậu tại khu vực có hoạt động xả thải tăng thêm khoảng 1,12 $\mathrm{mg} / \mathrm{l}$ so với công suất 420.000 tấn/năm. Phạm vi ảnh hưởng của việc xả thải trên sông Hậu lan truyền về phía thượng lưu và hạ lưu xa hơn so với Nhà máy đang hoạt động.
Kết quả cho thấy, khi triều rút, mức độ ảnh hưởng của việc xả thải đến nồng độ $\mathrm{BOD}_{5}$ của nước sông Hậu là khoảng $16,8 \mathrm{~km}$ về phía hạ lưu, vượt qua đầu cù lao Phong Nẫm khoảng $12,5 \mathrm{~km}$. Nồng độ $\mathrm{BOD}_{5}$ tại đầu cù lao Phong Nẫm tăng khoảng từ 1,2-1,6mg/1.

Khi triều lên, mức độ ảnh hưởng của việc- xả thải đến nồng độ $\mathrm{BOD}_{5}$ của nước sông Hậu là khoảng $8,7 \mathrm{~km}$ về phía thượng lưu, vượt qua đầu cù lao Mây khoảng 2,4km. Nồng độ $\mathrm{BOD}_{5}$ tại đầu cù lao Mây sẽ gia tăng khoảng từ 0,2$0,34 \mathrm{mg} / 1$.

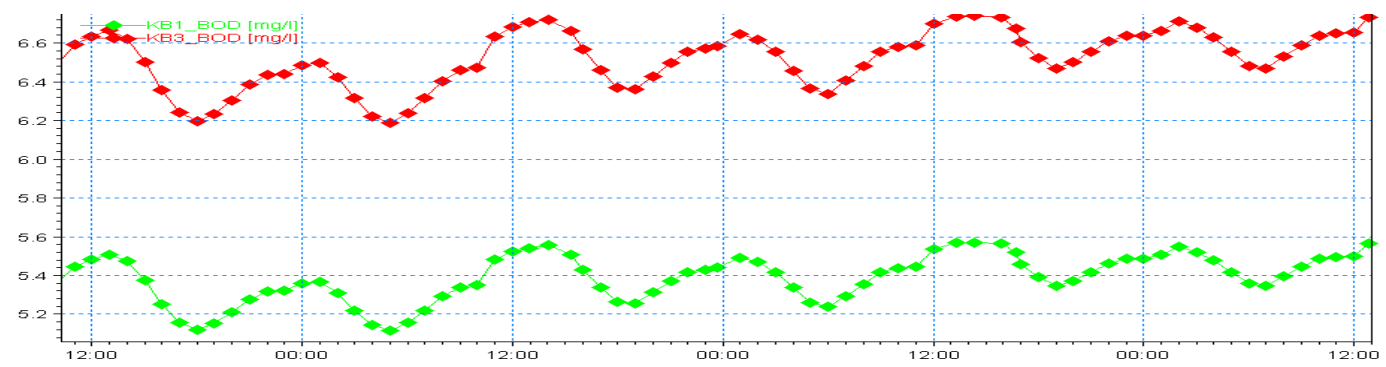

Hình 6. Thay đổi hàm luợng $B O D_{5}$ trên sông Hậu (KB3 và KB1)
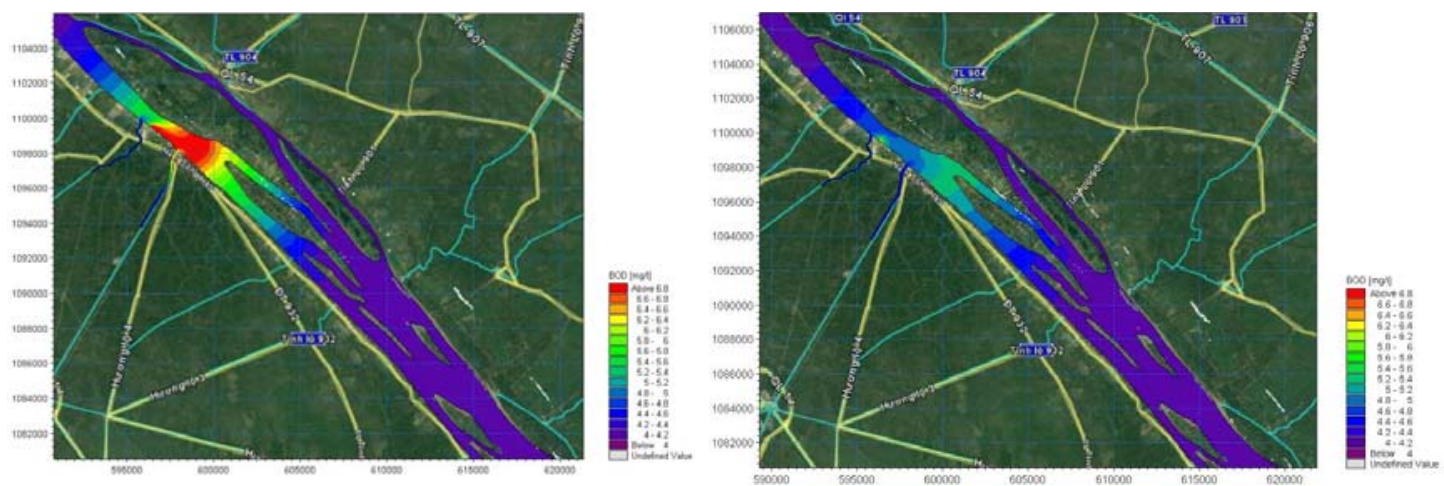

Hình 7. Phân bố $B O D_{5}$ trên sông Hậu khi triều rút (KB3 và KB1)
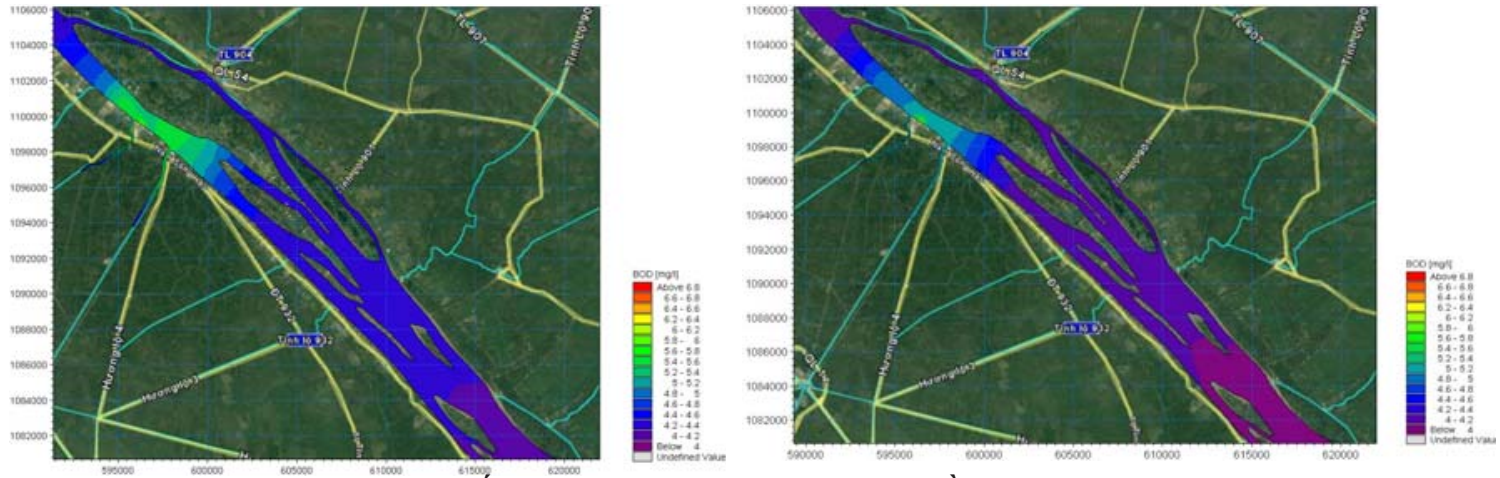

Hinh 8. Phân bố $B O D_{5}$ trên sông Hậu khi triều lên (KB3 và KB1)

- Hàm lượng COD trên sông Hậu tại khu vực

Dự án gia tăng lên so với kịch bản 1 khoảng $5,4 \mathrm{mg} / 1$. Phạm vi ảnh hưởng của việc xả thải trên sông Hậu về phía thượng lưu và hạ lưu lan truyền mạnh hơn so với kịch bản 1 .

Kết quả tính toán cho thấy, khi triều rút, mức độ ảnh hưởng của việc xả thải đến nồng độ COD của nước sông Hậu trong kịch bản 3 khoảng 
$27,5 \mathrm{~km}$ về phía hạ lưu, vượt qua đầu cù lao Phong Nẫm khoảng 21,6km. Nồng độ COD tại đầu cù lao Phong Nẫm sẽ gia tăng khoảng từ 1,9$3,2 \mathrm{mg} / 1$.

Khi triều lên, mức độ ảnh hưởng của việc xả thải đến nồng độ COD của nước sông Hậu trong kịch bản 3 khoảng 11,8km về phía thượng lưu, vượt qua đầu cù lao Mây khoảng 5,6km. Nồng độ COD tại đầu cù lao Mây sẽ gia tăng khoảng từ $0,2-0,4 \mathrm{mg} / 1$.

- Hàm lượng TSS trên sông Hậu tại khu vực sẽ tăng lên so với kịch bản 1 khoảng 1,5mg/l. Phạm vi ảnh hưởng của việc xả thải trên sông Hậu về phía thượng lưu và hạ lưu đều lan truyền mạnh hơn so với kịch bản 1 .

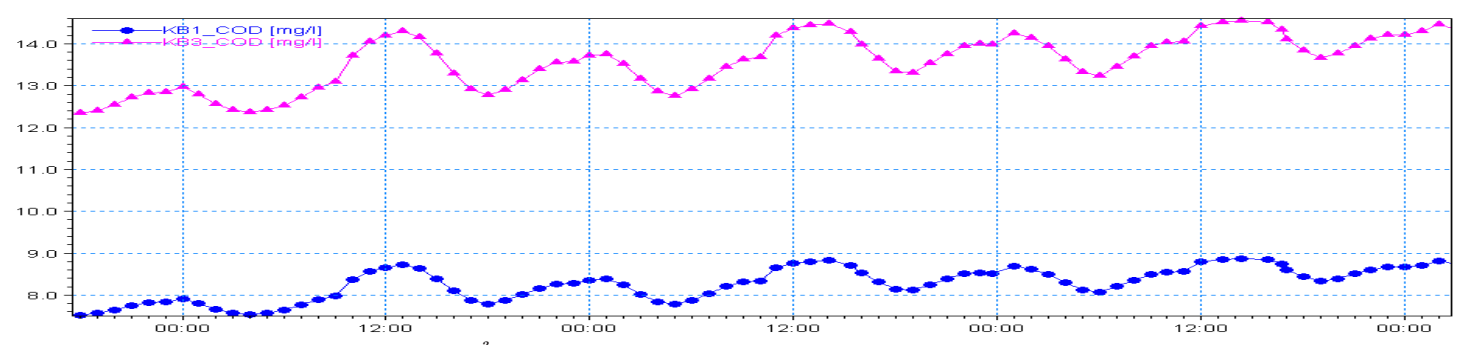

Hình 9. Thay đổi hàm lương COD trên sông Hậu (KB3 và KB1)
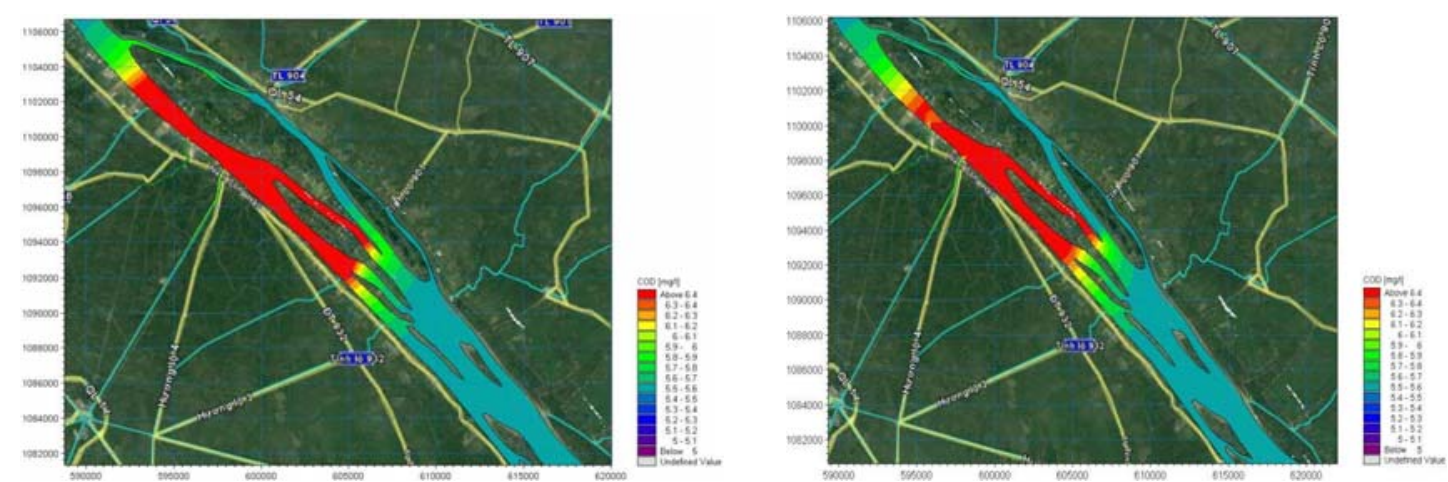

Hình 10. Phân bố COD trên sông Hậu khi triều rút (KB3 và KB1)
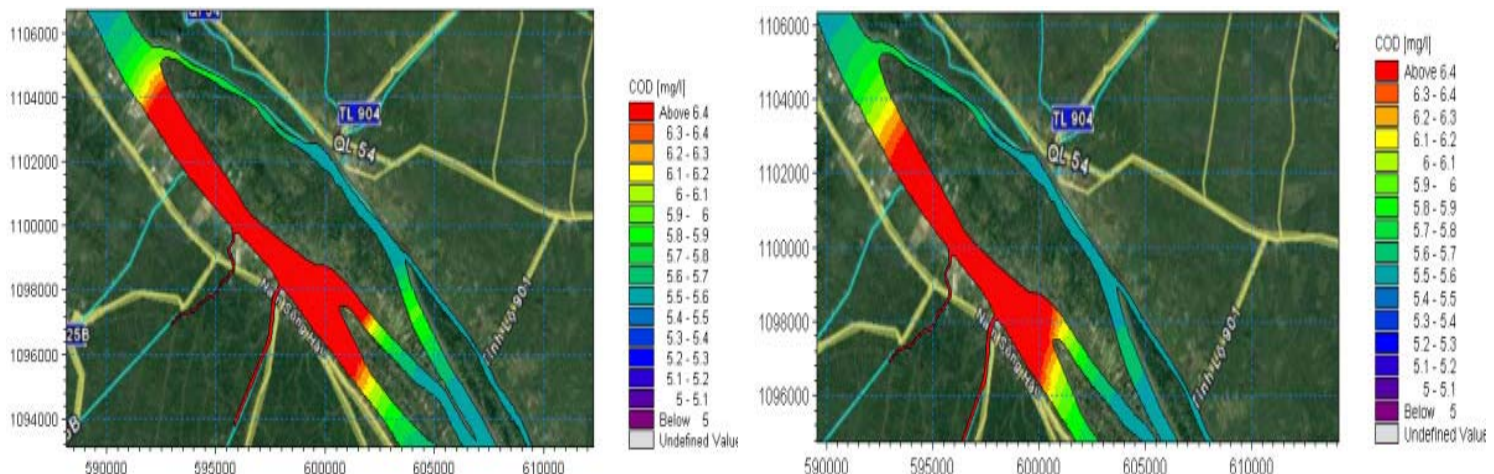

Hình 11. Phân bố COD trên sông Hậu khi triều lên (KB3 và KB1)
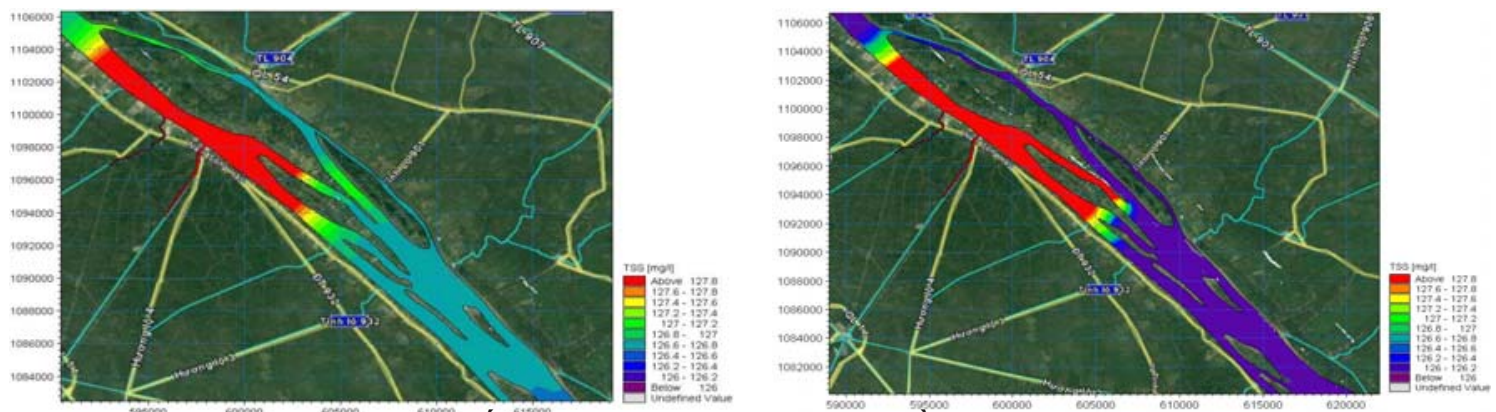

Hinh 12. Phân bố TSS trên sông Hậu khi triều rút (KB3 và KB 1 ) 

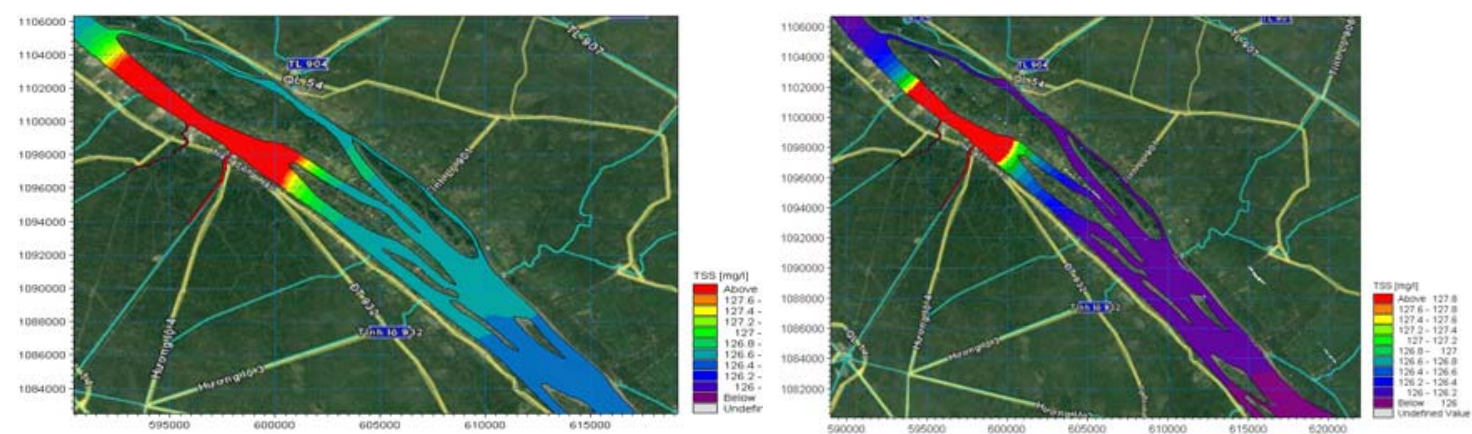

Hình 13. Phân bố TSS trên sông Hậu khi triều lên (KB3 và KB1)

\subsection{Kết quả tính với kịch bản 2, 4}

- Hàm lượng $\mathrm{BOD}_{5}$ trên sông Hậu tại khu vực gia tăng lên so với kịch bản 2 khoảng 0,1 $0,15 \mathrm{mg} / 1$, khi triều thấp, mức độ gia tăng càng lớn. Phạm vi ảnh hưởng của việc xả thải mở rộng về phía thượng lưu khoảng $1,2 \mathrm{~km}$; về hạ lưu khoảng $2,8 \mathrm{~km}$ so với hiện trạng. Chi tiết được thể hiện trong các hình từ 14 đến 16.

- Hàm lượng COD trên sông Hậu tại khu vực gia tăng lên so với kịch bản 2 từ $0,1-0,14 \mathrm{mg} / 1$, khi triều thấp, mức độ gia tăng càng lớn. Phạm vi ảnh hưởng của việc xả thải mở rộng về phía thượng lưu khoảng $2,4 \mathrm{~km}$; về hạ lưu khoảng $5,2 \mathrm{~km}$ so với hiện trạng.

- Hàm lượng TSS trên sông Hậu tại khu vực có xu hướng tăng lên so với kịch bản 2 từ 0,5 $0,9 \mathrm{mg} / 1$, khi triều thấp do hàm lượng TSS trong nước thải ra nhỏ hơn hàm lượng TSS trên sông. Nhìn chung tác động của TSS trong kịch bản này ảnh hưởng đến TSS trong sông do lưu lượng nước thải xả ra sông lớn.

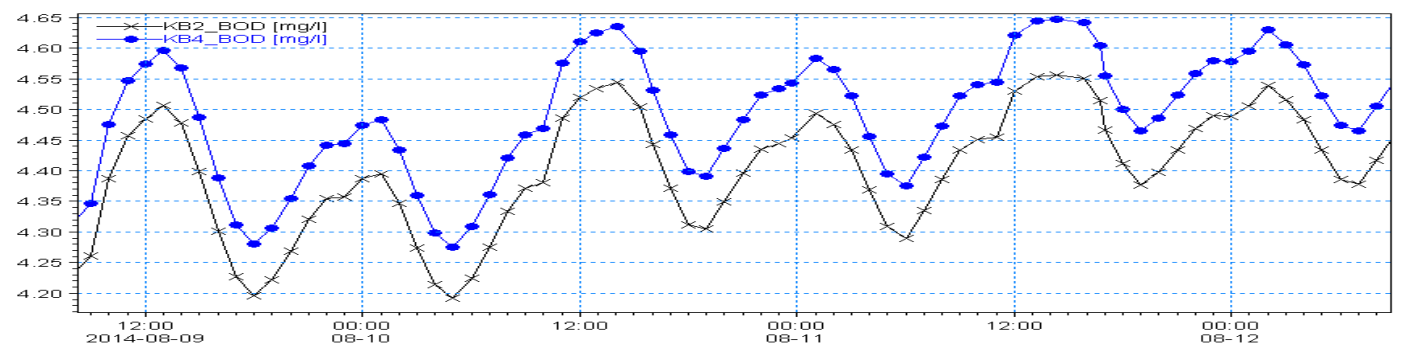

Hình 14. Thay đổi hàm lượng $B O D_{5}$ trên sông Hậu (KB4 và KB2)
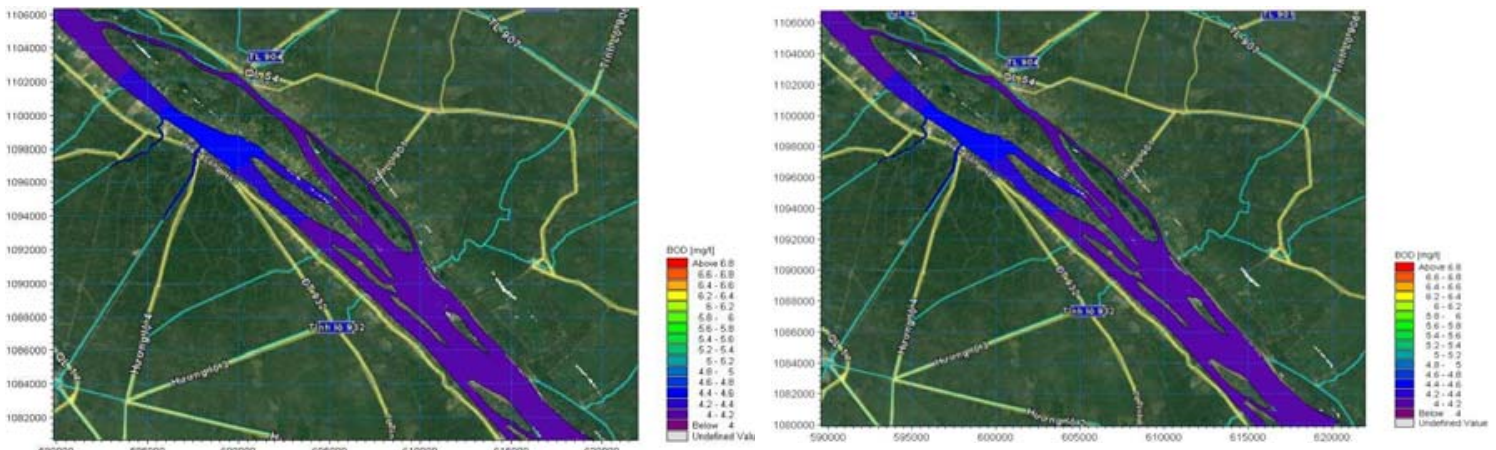

Hình 15. Phân bố $B O D_{5}$ trên sông Hậu khi triều rút (KB4 và KB2)
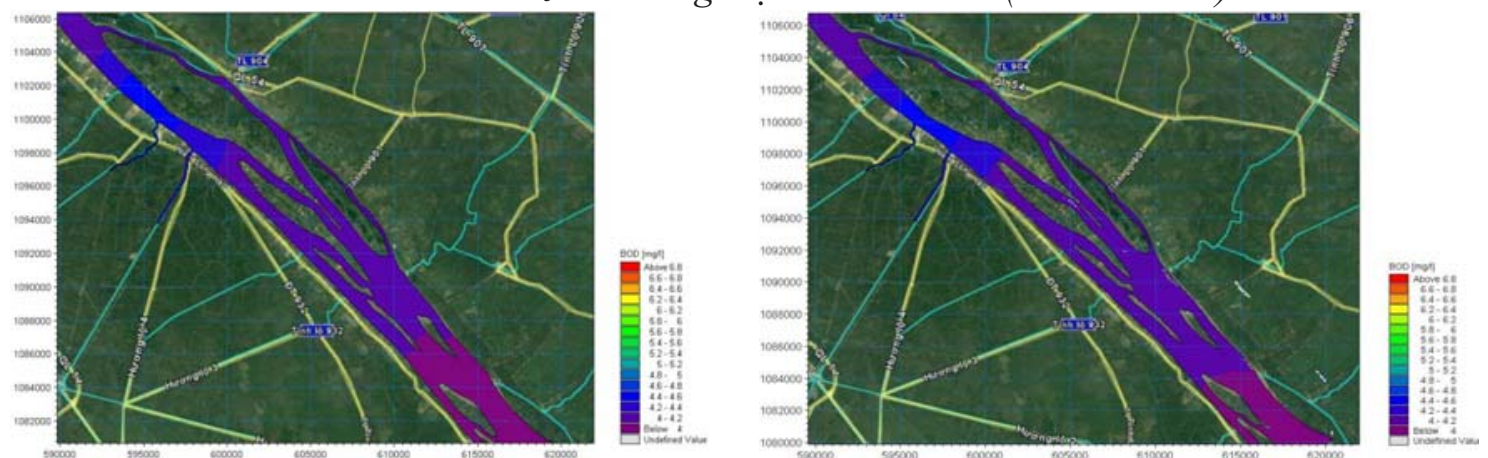

Hình 16. Phân bố $B O D_{5}$ trên sông Hậu khi triều lên (KB4 và KB2) 


\section{BÀI BÁO KHOA HỌC}

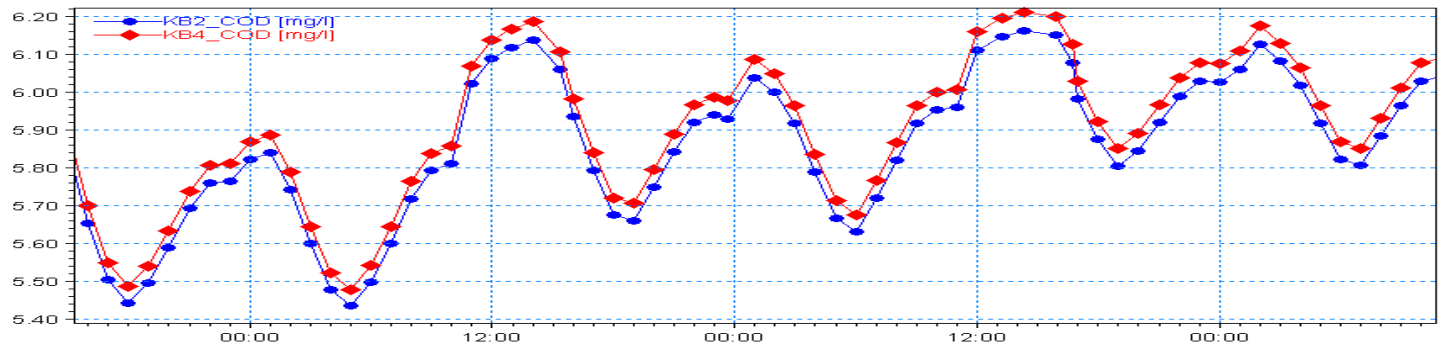

Hình 17. Thay đổi hàm lượng COD trên sông Hậu (KB4 và KB2)
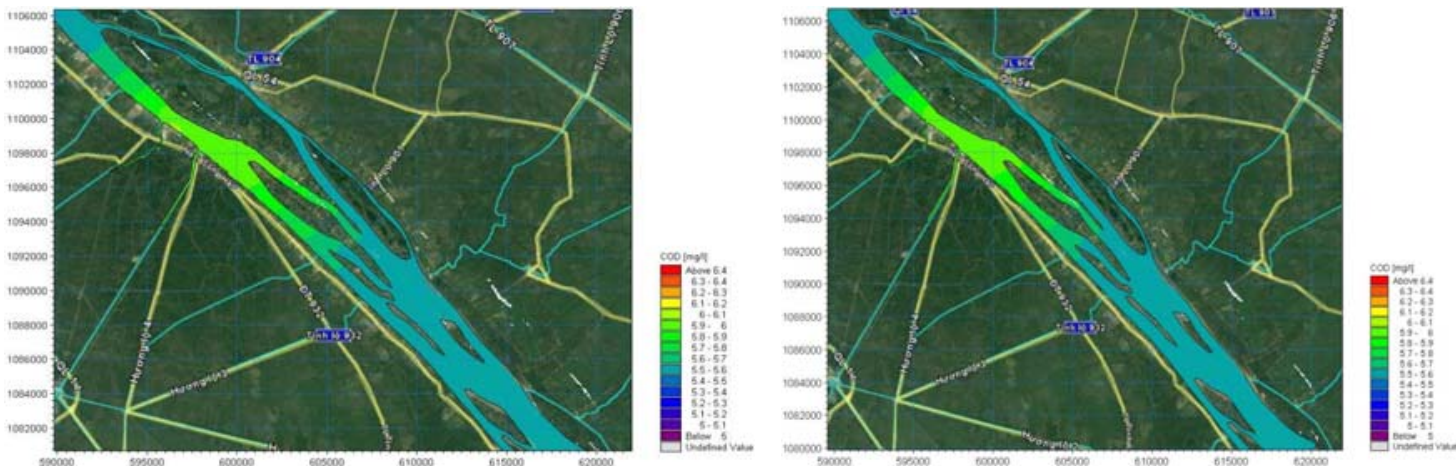

Hình 18. Phân bố COD trên sông Hậu khi triều rút (KB4 và KB2)
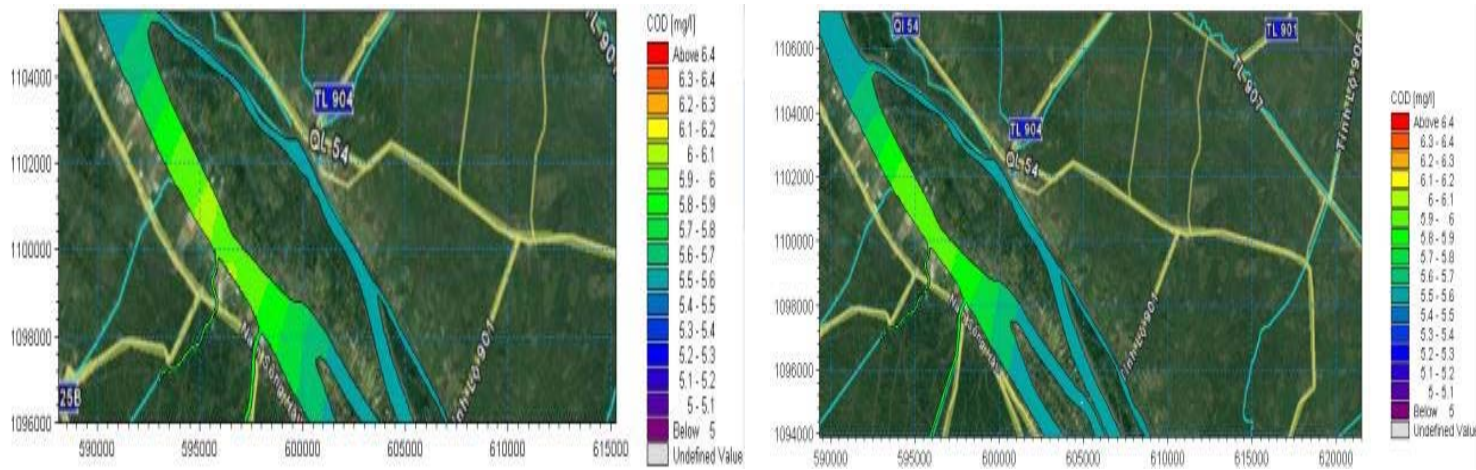

Hình 19. Phân bố COD trên sông Hậu khi triều lên (KB4 và KB2)

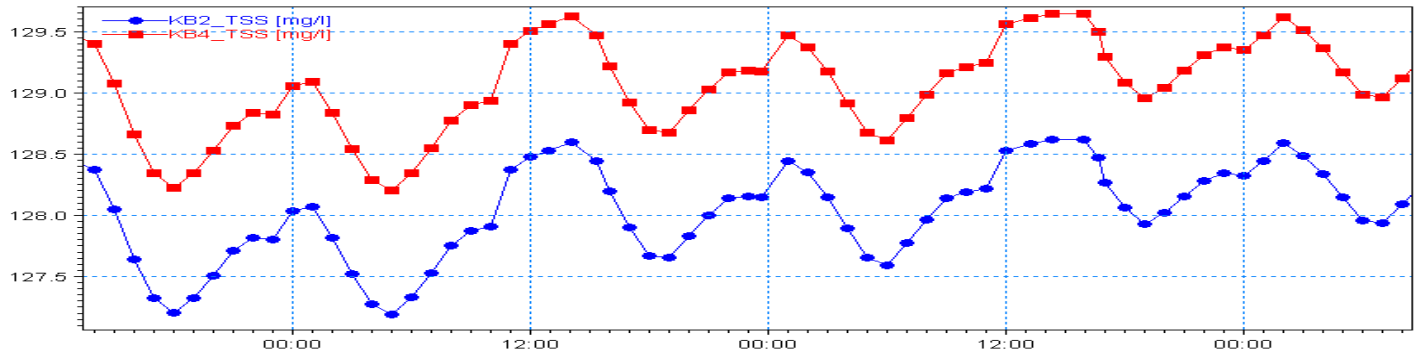

Hình 20. Thay đổi hàm lượng TSS trên sông Hậu tại khu vực Dự án (KB4 và KB2)
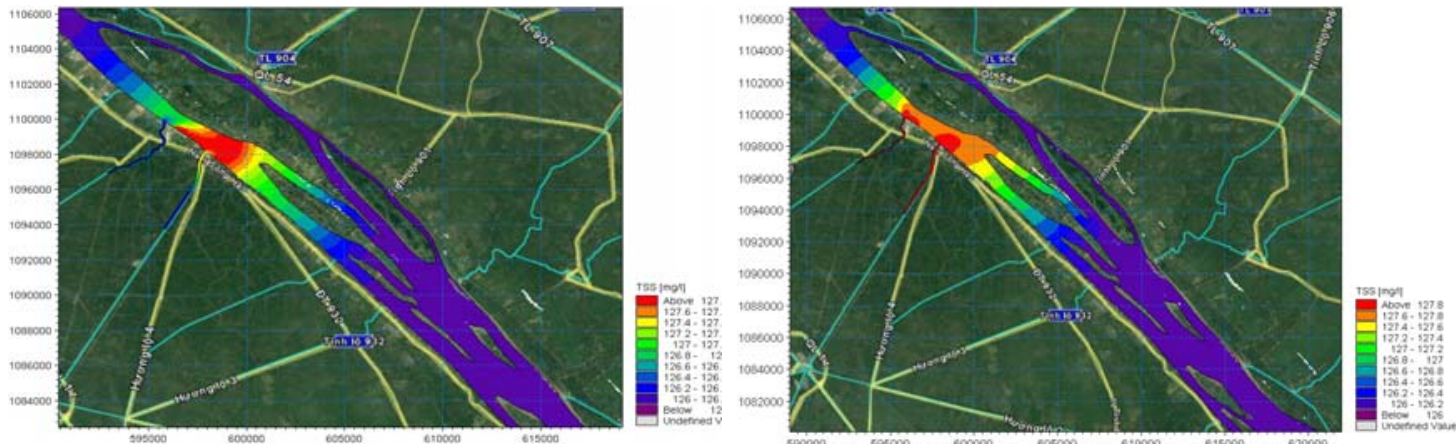

Hình 21. Phân bố TSS trên sông Hậu khi triều rút (KB4 và KB2) 


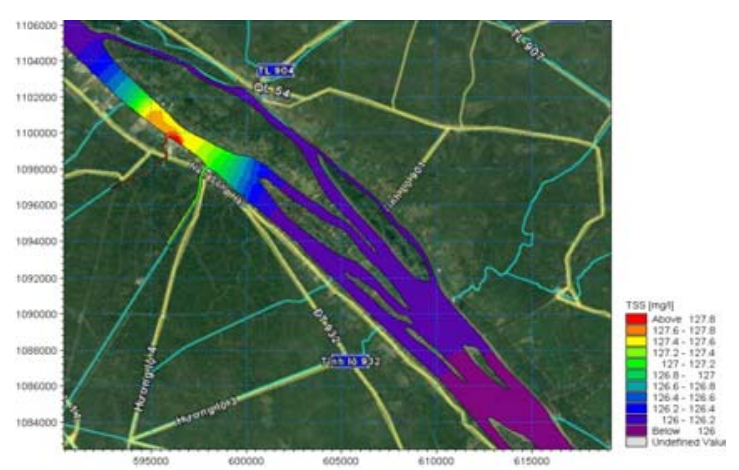

Hình 22. Phân bố TSS trên sông Hậu khi triều lên (KB4 và KB2)

\section{Kết luận}

Việc nâng công suất Nhà máy giấy Lee \& Man Việt Nam từ 420.000 tấn/năm lên 1.100 .000 tấn/năm kéo theo việc gia tăng lưu lượng xả nước thải từ $16.000 \mathrm{~m}^{3}$ lên $33.400 \mathrm{~m}^{3} /$ ngày đêm, đồng nghĩa với việc tăng hàm lượng các chất thải vào sông Hậu.

Đặc trưng của ngành tái chế giấy là chỉ số $\mathrm{BOD}_{5}, \mathrm{COD}$, TSS trong nước thải lớn, dưới tác động của quá trình động lực sẽ làm khuếch tán các chất ô nhiễm theo hướng dòng chảy. Sử dụng mô hình Mike để mô phỏng, so sánh biến động về lưu lượng, nồng độ một số chỉ số đặc trưng cho nước thải ngành giấy. 02 trường hợp với 04 kịch bản được so sánh là:

- Kịch bản 1, 3: Nước thải của Nhà máy Giấy công suất $420.000 ; 1.100 .000$ tấn/năm chưa được xử lý (rủi ro/sự cố) xả trực tiếp ra môi trường.

- Kịch bản 2, 4: Trường hợp nước thải của Nhà máy Giấy công suất 420.000 và 1.100 .000 xử lý đạt QCVN 12-MT:2015/BTNMT, 40:2011/BTNMT.

- Kết quả mô phỏng cho thấy:

+ Trong quá trình nâng công suất, trường hợp

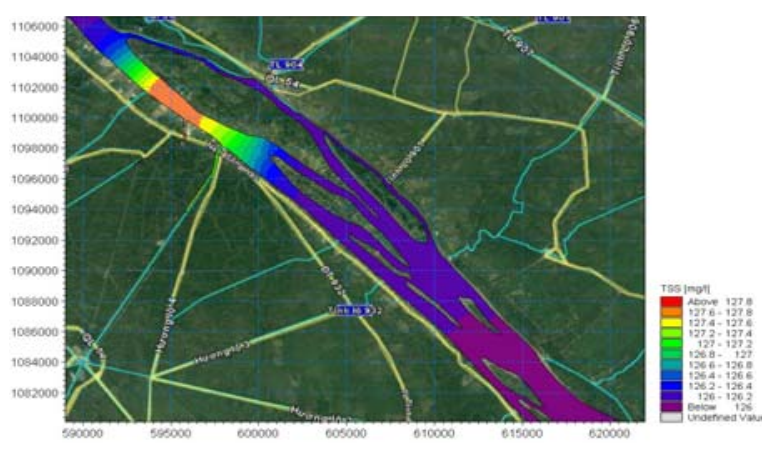

gặp rủi ro sự cố, nước thải không được xử lý thì: (1) hàm lượng $\mathrm{BOD}_{5}$ tăng khoảng 1,2-1,6mg/1 so với Nhà máy khi chưa nâng công suất, mức độ lan truyền lớn nhất có thể đạt tới $16,8 \mathrm{~km}$ về phía hạ lưu khi triều rút; (2) đối với chỉ tiêu COD, hàm lượng tăng lên từ 1,9-3,2 mg/1, phạm vi ảnh hưởng lan truyền khoảng $27,5 \mathrm{~km}$ về phía hạ lưu; (3) Khi nâng công suất, hàm lượng TSS trên sông Hậu sẽ tăng khoảng $1,5 \mathrm{mg} / 1$, vùng ảnh hưởng từ hoạt động xả thải sẽ mở rộng cả về phía thượng lưu và hạ lưu.

+ Trường hợp hệ thống xử lý nước thải của Nhà máy hoạt động ổn định, việc xả nước thải đáp ứng được QCVN 12-MT:2015/BTNMT, 40:2011/BTNMT, có biến động lớn về mặt lưu lượng tuy nhiên hàm lượng $\mathrm{BOD}_{5}, \mathrm{COD}$ và $\mathrm{TSS}$ biến động không lớn: (1) hàm lượng $\mathrm{BOD}_{5}$ sẽ tăng so với khi chưa nâng công suất từ 0,1 $0,15 \mathrm{mg} / \mathrm{l}$, phạm vi chịu ảnh hưởng cũng mở rộng hơn về phía thượng lưu khoảng $1,2 \mathrm{~km}$; về hạ lưu khoảng 2,8km; (2) chỉ tiêu COD biến động tăng từ $0,1-0,14 \mathrm{mg} / \mathrm{l}$; vùng ảnh hưởng mở rộng về thượng lưu khoảng $2,4 \mathrm{~km}$; về hạ lưu khoảng $5,2 \mathrm{~km}$; TSS biến động tăng từ $0,5-0,9 \mathrm{mg} / 1$, vùng ảnh hưởng không có biến động rõ rệt.

\section{Tài liệu tham khảo}

1. Nhà máy giấy Lee \& Man Việt Nam (2019), Báo cáo ĐTM Dự án Nâng công suất Nhà máy giấy Lee \& Man Việt Nam tù 420.000 lên 1.100.000 tấn/năm.

2. Viện KH Khí tượng Thủy văn \& Môi trường (2013), Đề tài mã số BĐKH.08, Nghiên cúu ảnh hương của biến đổi khí hậu đến sụ biến đổi tài nguyên nước đồng bằng sông Cửu Long.

3. Cấn Thu Văn, Nguyễn Thanh Sơn (2016), Nghiên cưu mô phỏng thủy văn, thủy lực vùng đồng bằng sông Cưu Long để đánh giá ảnh hưởng của hệ thống đê bao đến sụ thay đổi dòng chảy mặt vùng Đồng Tháp Mười. Tạp chí Khoa học ĐHQGHN: Các Khoa học Trái đất và Môi trường, 32 (3S), 256-263. 


\title{
PREDICTION OF THE CHANGES IN WATER QUALITY IN THE HAU RIVER DUE TO THE IMPROVEMENTS IN THE CAPACITY OF VIET- NAM LEE AND MAN PAPER MANUFACTURING LTD
}

\author{
Ngo Tra Mai ${ }^{1}$, Phan Thi Thanh Hang ${ }^{2}$ \\ ${ }^{1}$ Institute of Physics, Vietnam Academy of Science and Technology \\ ${ }^{2}$ Institute of Geography, Vietnam Academy of Science and Technology
}

\begin{abstract}
The capacity of Lee \& Man Paper manufacturing in Vietnam increases from 420,000 tons/year to 1,100,000 tons/year which will lead to an increase in waste water discharge from $16,000 \mathrm{~m}^{3} /$ day to $33,400 \mathrm{~m}^{3} /$ day, which means that the waste concentrations discharge into the Hau River will also increase. This study presents the results of applying MIKE model to simulate 04 scenarios of $\mathrm{BOD}_{5}, \mathrm{COD}$ and TSS which are typical components in wastewater of paper industry as a basis for predicting of water quality change in the Hau River.
\end{abstract}

Keywords: Paper manufacturing, wastewater and MIKE model. 